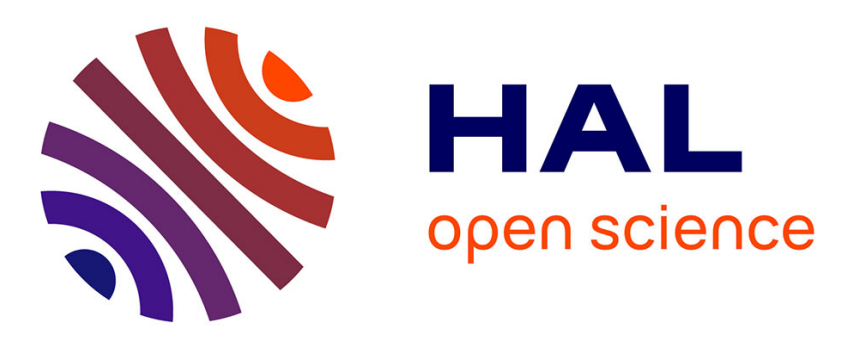

\title{
Ku86 is important for TrkA overexpression-induced breast cancer cell invasion
}

\author{
Chann Lagadec, Rodrigue Romon, Christophe Tastet, Samuel Meignan, \\ Emmanuelle Com, Adeline Page, Gabriel Bidaux, Hubert Hondermarck, \\ Xuefen Le Bourhis
}

\section{To cite this version:}

Chann Lagadec, Rodrigue Romon, Christophe Tastet, Samuel Meignan, Emmanuelle Com, et al.. Ku86 is important for TrkA overexpression-induced breast cancer cell invasion. PROTEOMICS Clinical Applications, 2010, 4 (6-7), pp.580-590. 10.1002/prca.200900148 . hal-03060333

\section{HAL Id: hal-03060333 https://hal.science/hal-03060333}

Submitted on 13 Dec 2020

HAL is a multi-disciplinary open access archive for the deposit and dissemination of scientific research documents, whether they are published or not. The documents may come from teaching and research institutions in France or abroad, or from public or private research centers.
L'archive ouverte pluridisciplinaire HAL, est destinée au dépôt et à la diffusion de documents scientifiques de niveau recherche, publiés ou non, émanant des établissements d'enseignement et de recherche français ou étrangers, des laboratoires publics ou privés. 
Ku86 is crucial for TrkA overexpression-induced breast cancer cell invasion

Chann Lagadec ${ }^{1 *}$, Rodrigue Romon ${ }^{1 *}$, Christophe Tastet ${ }^{1}$, Samuel Meignan ${ }^{1}$, Emmanuelle Com ${ }^{1}$, Adeline Page ${ }^{2}$, Gabriel Bidaux $^{3}$, Hubert Hondermarck $^{1}$ and Xuefen Le Bourhis $^{1}$

${ }^{1}$ INSERM U908, "Signalisation des facteurs de croissance dans le cancer du sein. Proteomique fonctionnelle", IFR-147, Université Lille 1, Villeneuve d'Ascq, France

${ }^{2}$ Centre Commun de Mesure de Spectrométrie de Masse, IFR-147, Université Lille 1, Villeneuve d'Ascq, France

${ }^{3}$ INSERM U800, "Laboratoire de Physiologie Cellulaire", IFR-147, Université Lille 1, Villeneuve d'Ascq, France

* The authors contributed equally to this work.

Correspondence: Professor H. Hondermarck, INSERM U908, Batiment SN3, Université Lille 1, 59655, Villeneuve d'Ascq, France

E-mail : hubert.hondermarck@univ-lille1.fr

Fax: $+33-3-20-43-40-38$

Abbreviations: RPLP0, human acidic ribosomal phosphoprotein P0; siRNA, smallinterfering RNA; TRAIL, TNF-related apoptosis inducing ligand

Keywords: breast cancer / Ku proteins / cell invasion / TrkA tyrosine kinase receptor 


\section{Abstract}

The Trk family of neurotrophin tyrosine kinase receptors is emerging as an important player in carcinogenic progression of non neuronal tissues. We have recently shown that breast tumors express high levels of TrkA compared to normal breast tissues, with TrkA overexpression enhancing breast cancer cell invasion in vitro and metastasis in animal models. Here we used a proteomic-based approach to identify proteins involved in TrkA overexpression-stimulated invasion of MDA-MB-231 breast cancer cells. Proteins from control and TrkA overexpressing cells were separated using a cup-loading two-dimensional electrophoresis system before MALDI and LC-MS/MS mass spectrometry analysis. Among several putative regulated proteins, Ku86 was found increased in TrkA overexpressing cells. Moreover, Ku86 was co-immunoprecipitated with TrkA, suggesting the interaction of these two proteins in TrkA overexpressing cells. Interestingly, inhibition with small-interfering RNA and neutralizing antibodies showed that Ku86 was required for TrkA-stimulated cell invasion. Together, these data allowed the identification of Ku86 as a new player involved in metastasis of breast cancer cells. 


\section{Introduction}

Several sets of growth factors and their cognate receptors are known to be involved in the regulation of cancer development [1-4]. Nerve growth factor (NGF) is the prototypic member of the neurotrophin family of proteins well known for promoting survival and differentiation of neuronal cells during nervous system development. However, accumulating data indicate that NGF is also involved in cancer development [5-7]. NGF exerts its effects through two membrane receptors: the tyrosine kinase receptor TrkA and the receptor $p 75^{\mathrm{NTR}}$, a common receptor for all neurotrophins and pro-neurotropins. NGF binding to TrkA induces TrkA receptor dimerisation and autophosphorylation of cytoplasmic tyrosines, leading to the activation of various signaling pathways, including the Ras/MAPK pathway, the PLC $\gamma$ pathway, and the PI3K/Akt pathway [7]. The biological consequences of TrkA activation vary according to cell types. Hence, TrkA activation induces differentiation of neuronal precursors and neuroblastoma cells [8], whereas it induces proliferation in breast adenocarcinoma cells $[9,10]$ and apoptosis in medulloblastoma cells [11].

Recently, we have shown that NGF and its tyrosine kinase receptor TrkA are overexpressed in breast cancers compared to normal breast tissues [12, 13]. Inhibition of NGF with neutralizing antibodies or small interfering RNA strongly reduces tumor growth and metastasis of breast cancer cells xenografted in immunodeficient mice [12]. Moreover, TrkA overexpression in breast cancer cells leads to a constitutive activation of its tyrosine kinase, resulting in an increased cell growth and tumorigenicity [13]. Together, these findings point out the importance of the NGF/TrkA axis in breast cancer development. In addition, upregulation of TrkA has also been shown in other cancers including thyroid [14], lung [15], pancreatic [16, 17], prostatic [18, 19] and ovarian carcinomas $[20,21]$. Thus, identification of molecules involved in the enhancement of aggressiveness of TrkA 
overexpressing cancer cells would be important for both better understanding of oncogenesis and research of new molecular targets. Here, we have used a functional proteomic approach to identify molecules involved in TrkA-mediated biological effects in breast cancer cells. We first separated proteins using a cup-loading two-dimensional electrophoresis (2D) system and then identified a series of putative modified proteins by MALDI and LC-MS/MS mass spectrometry analysis. We found that Ku86, initially described to form a heterodimer with ku70 to regulate DNA-dependent protein kinase (DNA-PK) that is crucial to DNA repair, was upregulated in TrkA overexpressing cells. Moreover, Ku 86 was required for TrkA-stimulated invasion of breast cancer cells. 


\section{Materials and methods}

\subsection{Materials}

Cell culture reagents were purchased from Bio-Whittaker (Emerainville, France). Recombinant NGF was from R\&D systems (Lille, France). Nucleofection reagents were from Amaxa Biosystems (Lonza, Cologne, Germany). Dynabeads protein A and protein G were obtained from Dynal Biotech (Invitrogene, Cergy Pontoise, France). Electrophoresis reagents, bicinchoninic acid reagents, protease inhibitor cocktail and rabbit polyclonal antiactin antibody were from Sigma (Saint-Quentin Fallavier, France). Sequencing grademodified trypsin was provided by Promega (Charbonnieres, France). ZipTip 18 pipette tips were obtained from Millipore (Molsheim, France). The monoclonal anti-Ku86 for immunofluorescence (S5C11) and neutralizing antibodies Anti-Ku70 (clone N3H10) and anti-Ku86 (clone 111 or S10B1) were purchased from Thermo Scientific (Courtaboeuf, France). For Western blotting, the polyclonal anti-Ku70 (AHP316), the monoclonal antiKu86 and the polyclonal anti-actin were purchased from AbD Serotec (Düsseldorf, Germany), GeneTex (Euromedex, Mundolsheim, France) and Sigma, respectively. The rabbit polyclonal anti-TrkA IgG was from Upstate-Millipore. Peroxidase-conjugated donkey anti-rabbit IgG and goat anti-mouse IgG were purchased from Jackson Immunoresearch Laboratories, Inc (Suffolk, UK). SuperSignal West Pico Chemiluminescent Substrate was from Pierce (Thermo Scientific). Lab-Tek chamber slides and Boyden chamber (8 mm) were obtained from Nalge Nunc International (Roskilde, Denmark). Alexa Fluor dyesconjugated secondary antibodies were from Invitrogen. siRNA were purchased from Eurogentec (Angers, France). 


\subsection{Cell Culture}

The MDA-MB-231 human breast cancer cell line was from the American Type Culture Collection. MDA-MB-231 TrkA overexpressing cells were stably transfected and characterized in our laboratory [13]. Cells were routinely maintained in EMEM supplemented with $2 \mathrm{mM} \mathrm{L-glutamine,} 1 \%$ non-essential amino acids, $10 \%$ fetal calf serum (FCS), $40 \mathrm{U} / \mathrm{ml}$ penicillin-streptomycin, $40 \mu \mathrm{g} / \mathrm{ml}$ gentamycin. All cells were cultured at $37^{\circ} \mathrm{C}$ in a humidified atmosphere of $5 \% \mathrm{CO}_{2}$.

\subsection{Protein extraction, separation and identification}

\subsubsection{Sample preparation and 2D electrophoresis}

Protein extraction was performed as previously described [22]. Isoelectric focusing was carried out using $18 \mathrm{~cm}$ Immobiline DryStrips pH 3-10 (GE Healthcare Bio-Sciences). IPG strips were reswollen overnight in $345 \mu$ l DeStreak (hydroxyethyl disulfide, GE Healthcare

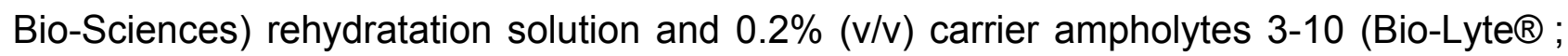
Bio-Rad), under $2 \mathrm{ml}$ mineral oil. Prior to IEF, protein samples (150 $\mu \mathrm{g}$ ) were first reduced $(1 \mathrm{~h})$ by adding tributylphosphine (TBP) to a final concentration of $5 \mathrm{mM}$ and secondly alkylated in the dark with $15 \mathrm{mM}$ iodoacetamide for $90 \mathrm{~min}$ at room temperature. The samples were then cup-loaded near the anode of the IPG strips and focused in a Protean IEF cell (Bio-Rad) at a temperature of $20^{\circ} \mathrm{C}$. The IPG strips were initially conditioned for $30 \mathrm{~min}$ at $250 \mathrm{~V}$ (rapid voltage ramping), linearly ramped to $1,000 \mathrm{~V}(1 \mathrm{~h})$ and maintained at $1,000 \mathrm{~V}$ for $1 \mathrm{~h}$ more. Then the electric voltage was slowly increased to reach $10000 \mathrm{~V}$ in $1 \mathrm{~h}$ and focused at this voltage to give a total of $60 \mathrm{kVh}$. After focusing, the strips were equilibrated for $2 \times 15 \mathrm{~min}$ in $6 \mathrm{M}$ Urea, 30\% w/v glycerol, 2\% w/v SDS, $0.125 \mathrm{M}$ Tris, 0.1 $\mathrm{M} \mathrm{HCl}$, containing either $50 \mathrm{mM}$ DTT (first equilibration step) or $150 \mathrm{mM}$ iodoacetamide (second equilibration step) [23]. Second-dimension electrophoresis (SDS-PAGE) was 
performed as previously reported [24]. The gel patterns were visualized by silver nitrate staining [25] for analytical purposes or by colloidal CBB G-250 [26] in the case of micropreparative separations.

\subsubsection{D gel evaluation}

Digitalized images of 2D gels were acquired by scanning with a GS-800 calibrated densitometer under control of PDQuest Advanced software version 8.0 (Bio-Rad), which was also used for image analysis and construction of a local 2D database. Image alignment, spot detection, background removal and expression analysis were performed using PDQuest Advance software. Fold changes and all statistical analysis were calculated based on normalized spot volumes where the global spots volume was used to perform normalization. A total of three gels per protein extraction and 3 extractions from independent experiments were made (9 gels in total per condition) for the study.

\subsubsection{Immunoprecipitation and SDS-PAGE}

Cells were harvested by scraping in lysis buffer $(50 \mathrm{mM}$ Tris- $\mathrm{HCl} \mathrm{pH} \mathrm{7.5,} 150 \mathrm{mM} \mathrm{NaCl}$, $1 \%$ NP40, $1 \mathrm{mM}$ sodium orthovanadate and protease inhibitor cocktail). After centrifugation $\left(10,000 \mathrm{~g}, 3 \mathrm{~min}, 4^{\circ} \mathrm{C}\right)$, the supernatant proteins were quantified using the bicinchoninic acid method. TrkA and interacting proteins were co-immunoprecipitated from $5 \mathrm{mg}$ of proteins using $25 \mu \mathrm{g}$ of anti-TrkA antibody (Upstate) and Dynabeads protein A according to manufacturer's instructions. Immunoprecipitated proteins were eluted in Laemmli buffer (62.5 mM Tris- $\mathrm{HCl}$ pH 6.8, 2\% SDS, 10\% glycerol, 5\% 2-mercaptoethanol and $0.002 \%$ bromophenol blue) and boiled 5 min before analysis on $10 \%$ polyacrylamide gels. For staining, SDS-polyacrylamide gels were fixed overnight in solution containing $50 \%$ ethanol and $1.4 \%$ orthophosphoric acid. After 3 washes for 30 min in MilliQ water, gels were incubated in impregnation solution (1.3 M ammonium sulfate, $34 \%$ methanol, 
$1.4 \%$ orthophosphoric acid) for $1 \mathrm{~h}$ and placed in staining solution (1.3 $\mathrm{M}$ ammonium sulfate, $34 \%$ methanol, $1.4 \%$ orthophosphoric acid, 0.07\% Coomassie Brillant Blue G250) for 24 h. Finally, gels were destained with several washes of MilliQ water until the backgroung was clear.

\subsubsection{In gel trypsin digestion and protein identification by mass spectrometry}

Coomassie blue-stained protein bands were excised from SDS-PAGE gel and processed for trypsin digestion as previously described [27]. Protein identification was realized using both MALDI-TOF (Voyager DE STR instrument, Applied Biosystems) and NanoLCNanoESI-MS/MS (LCQ Deca XP+, Thermo-electron, San Jose, CA) as previously described [27]. Database searching was done with SwissProt 56.8 (410,518 sequences; $148,080,998$ residues). To ascertain unambiguous identification, searches were performed in parallel with Phenyx software using the same parameters.

\subsection{Immunoassays}

\subsubsection{Western blot}

After 2D electropheresis or SDS-PAGE separation, proteins were electro-transferred onto nitrocellulose membrane using a semi-dry transfer system (Trans-Blot SD cell, Bio Rad). Non specific protein binding sites were saturated for $1 \mathrm{~h} 30$ at room temperature in TBS$0.1 \%$ Tween-20 reagent (TBST) containing either 5\% BSA for Ku70, ku86 and actin immunodetection. Membranes were then incubated overnight at $4^{\circ} \mathrm{C}$ with 1:5000 antiKu70, 1:500 anti-Ku86, 1:500 anti-TrkA or 1:5000 anti-actin antibodies. After washes in TBST, peroxidase-conjugated anti-rabbit or anti-mouse lgG diluted in saturated solution was added for $1 \mathrm{~h}$ at room temperature and the membranes were washed several times in TBST before detection of peroxidase activity using chemiluminescent system. 


\subsubsection{Flow cytometry}

Cells detached by Trypsin-EDTA solution were incubated for $1 \mathrm{~h}$ at $4^{\circ} \mathrm{C}$ with $20 \mu \mathrm{g} / \mathrm{ml}$ of the indicated antibodies or matched control isotypes at similar concentrations. After washing with PBS containing $0.5 \% \mathrm{BSA}$, cells were incubated for $30 \mathrm{~min}$ at $4^{\circ} \mathrm{C}$ with secondary fluorescein-labelled IgG. Cells were then analyzed in Coulter Epics XL/XL-MCI cytometer (Beckman Coulter, Villepinte, France).

\subsubsection{Immunocytochemistry and confocal microscopy}

MDA-MB-231 cells were seeded on Lab-tek chamber slides precoated with type I collagen. Cells were washed in PBS pH 7.5, fixed in 4\% paraformaldehyde for 20 min. Non specific protein binding sites were then blocked in PBS pH 7.5 containing $2 \% \mathrm{BSA}$ and cells were incubated in blocking solution containing $10 \mu \mathrm{g} / \mathrm{ml}$ rabbit anti-TrkA and $10 \mu \mathrm{g} / \mathrm{ml}$ mouse anti-Ku70 or anti-Ku86 antibodies overnight at $4^{\circ} \mathrm{C}$. After washes in PBS pH 7.5, $10 \mu \mathrm{g} / \mathrm{ml}$ Alexa Fluor 546 goat anti-rabbit IgG and $10 \mu \mathrm{g} / \mathrm{ml}$ Alexa Fluor 488 donkey anti-mouse lgG were added for $1 \mathrm{~h}$ at $37^{\circ} \mathrm{C}$. Cells were washed in PBS pH-7.5 and mounted. Scanning fluorescence images were acquired using a Zeiss Axiophot microscope.

\subsection{Real Time PCR (RT-PCR)}

RNA extraction and real time PCR amplifications were performed as previously described [27]. The primers used were as following : 5'-CCCCAATTCAGCAGCATATT-3' and 5'CCTTCAGCCAGACTGGAGAC-3' for Ku86, 5'-AAAAGACTGGGCTCCTTGGT-3' and 5'TGTGGGTCTTCAGCTCCTCT-3' for Ku70, 5-GTGATGTGCAGCTGATCAAGACT-3 and 5-GATGACCAGCCCAAAGGAGA-3 for RPLPO (human acidic ribosomal phosphoprotein P0), which was used as a reference gene. The amplification was performed during 40 cycles $\left(95^{\circ} \mathrm{C}\right.$ for $20 \mathrm{sec}$, at $55^{\circ} \mathrm{C}$ for $30 \mathrm{sec}$, and at $72{ }^{\circ} \mathrm{C}$ for $30 \mathrm{sec}$ ). Data were analyzed using the MX4000 PCR system software (Stratagene, Amsterdam, The Netherlands) with 
the SYBRGreen option (with dissociation curves).

\section{6 siRNA transfection}

MDA-MB-231 cells $\left(2 \times 10^{6}\right)$ were transiently transfected with $3 \mu \mathrm{g}$ of siKu70 and/or siKu86 using the nucleofection technology (Amaxa Biosystems) according to manufacturer's instructions. Sequences of 5'-GAUGCCCUUUACUGAAAAA-3' and 5'-UUUUUCAGUAAAGGGCAU-3' were used as sense and antisense for siKu70, 5'-CCAGGUUCUCAACAGGCUG-3' and 5'-CAGCCUGUUGAGAACCUGG-3' were used as sense and antisense for siKu86. siRNA against GFP (sense 5'GCUGACCCUGAAGUUCAU-3', antisense 5'-GAUGAACUUCAGGGUCAG-3') were used as control. Twenty-four hours after transfection, cells were seeded for the evaluation of apoptosis induction or invasion.

\subsection{Invasion assay}

BD Falcon inserts with a PET membrane/ $6.5 \mu \mathrm{m}$ pores (BD Biosciences) were used for invasion assay. The inserts were pre-coated with GFR Matrigel (1:10 dilution, BD Biosciences). Cells $\left(5 \times 10^{4}\right)$ were seeded on polycarbonate membrane insert and maintained in EMEM containing $0.1 \%$ FCS. For antibody neutralization, cells were pretreated with $20 \mu \mathrm{g} / \mathrm{ml}$ of neutralizing antibodies against Ku70 and Ku86 during 30 min before seeding. After $16 \mathrm{~h}$ of culture, the insert was washed with PBS, and cells on the top surface of the insert were removed by wiping with a cotton swab. Cells that invaded the Matrigel and migrated to the bottom surface of the insert were fixed with methanol, stained by Hoechst 33258 and then counted on 10 random fields at 200 magnification under a Nikon Eclipse Ti-U fluorescent microscope. 


\subsection{Apotosis analysis}

Cells were treated with $5 \mathrm{ng} / \mathrm{ml}$ TNF-related apoptosis inducing ligand (TRAIL) for $6 \mathrm{~h}$. Apoptosis was determined by morphological analysis after fixation with methanol (10 min, $20^{\circ} \mathrm{C}$ ) and staining with $1 \mu \mathrm{g} / \mathrm{ml}$ Hoechst 33258 (10 min, room temperature, in the dark). A minimum of 500-1000 cells was examined for each case under fluorescent microscope and the results represented the number of apoptotic cells over the total number of counted cells.

\subsection{Statistical analysis}

Statistical significances were determined with two-tailed Student's $t$ tests. All $p$ values were two-sided. $p<0.01$ was considered as statistically significant. 


\section{Results}

\subsection{Ku86 is upregulated in breast cancer cells overexpressing TrkA}

Proteins of mock and TrkA overexpressing MDA-MB-231 cells were separated by 2D electrophoresis before analysis of protein spots with PDquest software. A representative example of proteins separated on 2D-gel is shown in Figure 1A. Nearly 1500 spots were obtained in the ranges of MW 12-120 kDa and pl 3-10. In TrkA overexpressing cells, more than 20 spots were found to be down- or upregulated after analysis with PDquest software. Proteins were identified by MALDI-TOF and LC-MS/MS. Among a dozen of differentially expressed proteins which remain to be validated, a significant increase of Ku86 protein was observed in TrkA overexpressing cells. Interestingly, Ku86 was found as a set of four close spots in both mock and TrkA overexpressing cells (Fig. 1B). MALDITOF spectrum showed 25 experimental tryptic peptides that matched to theoretical masses, leading to $32.5 \%$ sequence coverage with an average error mass of $0.034 \mathrm{Da}$ (Fig. 1C, Table 1A). This identification was consolidated by independent MS/MS analysis of corresponding spot from 2D gel, as sequencing of five peptides revealed $8 \%$ sequence coverage with an average error mass of 0.295 Da (Fig. 1D and E, Table 1B). Importantly, Western blotting analysis also showed a similar increase of Ku86 in TrkA overexpressing cells (Fig. 2A and B), thus validating the 2D electrophoresis and mass spectrometry analysis. However, real time PCR showed no modifications of Ku86 mRNA (Fig. 2C), indicating that Ku86 upregulation is post-translationally controlled.

\subsection{Ku 86 is co-immunoprecipitated with TrkA}

Ku 86 and ku70 can be associated to form a heterodimeric regulatory subunit of the DNAdependent protein kinase (DNA-PK) that is crucial to DNA repair [28]. Ku proteins are also reported to be involved in cell proliferation, migration and invasion [29]. More recently, we 
have shown that Ku70 interacts with TrkA in MCF-7 breast cancer cells to stimulate cell survival in TRAIL-induced apoptosis [27]. To determine if TrkA interacts with Ku proteins in MDA-MB-231 TrkA overexpressing cells, we identified TrkA co-immunoprecipitated proteins by mass spectrometry LC-MS/MS. Both Ku86 and Ku70 were found to be immunoprecipitated with TrkA. Identification of Ku86 was made based on the sequencing of 3 peptides (556.88; 689.45; 690.88) (Fig. 3A and B), with a Mascot score of 208 and 4 $\%$ coverage (blanket). On the other hand, 2 peptides corresponding to Ku70 were also sequenced (586.71 and 568.63), with a Mascot score of 48 and $3 \%$ of coverage (Fig. 3C). Moreover, Western blot confirmed the presence of both Ku86 and ku70 in TrkA coimmunoprecipitated proteins (Fig. 3D).

\subsection{Membrane Ku86 and Ku70 are increased in TrkA overexpressing cells}

Increased levels of Ku86 in TrkA overexpressing cells as well as the association of Ku proteins with TrkA prompted us to determine the levels of membrane Ku proteins by flow cytometry analysis. As shown in Fig. 4 A and B, an increase of membrane Ku86 and Ku70 was observed in TrkA overexpressing cells compared to mock ones. We then analysed subcellular distribution of these proteins in TrkA overexpressing cells by confocal microscopy after immunochemical staining (Fig. 4C). TrkA (blue fluorescence) and Ku proteins (green fluorescence) seemed to be mainly located in the nucleus and cytoplasmic membrane, though a faint and punctuate staining was also observed in the cytoplasm.

\subsection{Ku86 is involved in TrkA-induced cell invasion}

We have previously shown that TrkA overexpression leads to an increase in invasion and survival of breast cancer cells [13]. To determine whether Ku proteins were implicated in TrkA-overexpression-induced biological effects, we inhibited Ku proteins by siRNA or neutralizing antibodies. As shown in Fig. 5A, specific siRNAs strongly decreased the 
expression of Ku86 and Ku70. Inhibition of Ku86 with both siRNA and the neutralizing antibody efficiently reduced invasion of TrkA overexpressing cells, while inhibition of Ku70 had no effect (Fig. 5B and C). Interestingly, simultaneous inhibition of both Ku86 and Ku70 did not reduce more than inhibition of Ku86 alone. We then evaluated if Ku proteins could regulate apoptosis induction in TrkA overexpressing cells. For this, we transfected cells with siKu and then treated them with TRAIL (TNF-related apoptosis inducing ligand), a cytokine well known for apoptosis induction in breast cancer cells. As shown in Fig. 5D, siKu86 had no effect on apoptosis of cells whatever TRAIL treatment. In contrast, siKu70 induced apoptosis even in the absence of TRAIL and could further increase apoptosis induction by TRAIL, confirming our previous finding in MCF-7 breast cancer cells [27]. When cells were co-transfected with siKu86 and siKu70, no significant difference was observed compared to siKu70 alone-transfected cells. All together, these results indicated that $\mathrm{Ku}$ proteins functioned independently of each other to mediate TrkA overexpressioninduced biological effects: Ku86 was only involved in cell invasion while Ku70 was implicated in cell survival. 


\section{Discussion}

We have previously shown that TrkA overexpression increases breast cancer cell growth, invasion, as well as survival. In order to understand the underlying mechanisms, we have used a functional proteomic approach to identify molecules involved in the TrkA-mediated biological effects. We first separated proteins using 2D electrophoresis system and then identified a series of putative modified proteins in TrkA overexpressing cells by MALDI and LC-MS/MS mass spectrometry analysis. The cup-loading technology allows rapid identification of protein changes between samples on reproducible $2 \mathrm{D}$ gels and reduces the inter-experimental variations. Among a dozen of differentially expressed proteins, which remain to be validated, we observed a significant increase of Ku86 in TrkA overexpressing cells, as revealed by direct quantification of corresponding spots in 2D gels and Western blot analysis. This is of particular interest, as we have recently identified another member of the Ku family of proteins, namely Ku70, as a partner of TrkA signaling in breast cancer cells [27]. Indeed, we have shown that NGF treatment induces tyrosine phosphorylation of Ku70 upon its association to TrkA. Moreover, Ku70 is involved in TrkAenhanced cell survival [27]. Here, we only found that Ku86 was upregulated in TrkA overexpressing cells, although both ku70 and ku86 were co-immunoprecipitated with TrkA. Visualisation of Ku86 as four close spots in 2D gels may be due to post-translational modifications, as Ku proteins have been described to be acetylated and phosphorylated $[27,30,31]$. In spite of the increase of protein levels, we were not able to observe any significant variation of Ku86 mRNA level by real time PCR, suggesting a mechanism of regulation at post-transcriptional level. Reinforcing this hypothesis, it has been recently described that VEGF can activate AKT which in turn inhibits Ku70 proteolysis by phosphorylating Hdm2, the ubiquitin ligase of Ku70 [32]. Thus, further studies will be needed to examine the exact underlying mechanism of Ku86 upregulation in our model. 
The fact that Ku86 was upregulated in TrkA overexpressing breast cancer cells is in line with previous demonstration that Ku86 is expressed in abundant levels in tissues with a high proliferative index or in cells stimulated to proliferate [33,34]. Moreover, upregulation of Ku proteins has been associated with the progression of some types of tumors. For instance, the levels of Ku86 are positively correlated with that of anti-apoptotic Bcl-2 in B cell chronic lymphocytic leukemia [35]. Ku86 has also been reported to be upregulated in bladder, breast and primary hepatocellular carcinomas, compared to adjacent non tumorous tissues [36-38].

Ku86 and Ku70 are mainly localized in the nucleus, where they form heterodimers to recruit the catalytic subunit of DNA dependent protein kinase (DNA-PKcs), which is involved in multiple biological processes such as DNA double-strand break repair, telomere length maintenance, cell cycle progression and transcriptional regulation [31, 39]. However, cytosolic and membrane Ku proteins are increasingly reported to exert different functions independently of each other. Cytosolic Ku70 has been shown to bind to the proapoptotic protein Bax and inhibit Bax-mediated apoptosis by preventing its translocation to mitochondria. This anti-apoptotic function is mediated by a domain in the carboxy-terminal of Ku70 and does not require the cooperative effects of Ku86 [40]. Accordingly, here we showed that Ku70 but not Ku86 was involved in the increased survival of TrkA overexpressing breast cancer cells. On the other hand, membrane Ku proteins have been reported to be associated with cell adhesion and migration $[41,42]$. It has been shown that hypoxia-stimulated invasion of neuroblastoma and breast carcinoma cells involves upregulation of membrane Ku86 [43]. Similarly, Ku proteins are found to interact with metalloproteinase 9 at the membrane of highly invasive normal and tumoral hematopoietic cells [44]. Translocation of Ku proteins from the nucleus to the plasma membrane can enhance migration of monocytes [45]. In this study, we found an increase of membrane 
Ku86 and Ku70 in TrkA overexpressing cells. Moreover, inhibition of Ku86 with siRNA or neutralizing antibodies strongly reduced TrkA-stimulated invasion, indicating that Ku86, especially membrane Ku86, was involved in this process. Our previous work shows that activation of signalling pathways including PI3/AKT and MAP kinases is required for TrkA overexpression-enhanced cell invasion and survival [13]; here we showed that Ku86 was involved in TrkA-overexpression-stimulated cell invasion while Ku70 was only implicated in TrkA-overexpression-enhanced cell survival. Thus, it will be interesting to determine the link between classical signaling pathways and the specific implication of Ku proteins in these processes.

In conclusion, we showed by functional proteomic exploration that Ku86 is upregulated in TrkA overexpressing breast cancer cells and is involved in TrkA-induced cell invasion. Therefore, upregulation of Ku86 in tumor cells overexpressing TrkA might be a mechanism leading to an increase of metastasis. Although further in vitro and in vivo investigations will be required to test this hypothesis, these data reveal Ku86 as a new potential player in the intracellular signalling leading to breast cancer cell metastasis. 


\section{Acknowledgments}

Grant support: INSERM, la Ligue Nationale Contre le Cancer (Equipe labellisée 2009), le Ministère de l'Education Nationale and la Région Nord-Pas-de-Calais. 
The authors have declared no conflict of interest. 


\section{References}

[1] Chan, S. K., Hill, M. E., Gullick, W. J., The role of the epidermal growth factor receptor in breast cancer. J Mammary Gland Biol Neoplasia 2006, 11, 3-11.

[2] Chang, C. F., Westbrook, R., Ma, J., Cao, D., Transforming growth factor-beta signaling in breast cancer. Front Biosci 2007, 12, 4393-4401.

[3] Mercurio, A. M., Lipscomb, E. A., Bachelder, R. E., Non-angiogenic functions of VEGF in breast cancer. J Mammary Gland Biol Neoplasia 2005, 10, 283-290.

[4] Roussidis, A. E., Theocharis, A. D., Tzanakakis, G. N., Karamanos, N. K., The importance of c-Kit and PDGF receptors as potential targets for molecular therapy in breast cancer. Curr Med Chem 2007, 14, 735-743.

[5] Papatsoris, A. G., Liolitsa, D., Deliveliotis, C., Manipulation of the nerve growth factor network in prostate cancer. Expert Opin Investig Drugs 2007,16, 303-309.

[6] Nakagawara, A., Trk receptor tyrosine kinases: a bridge between cancer and neural development. Cancer Lett 2001, 169, 107-114.

[7] Dolle, L., Adriaenssens, E., El Yazidi-Belkoura, I., Le Bourhis, X., et al., Nerve growth factor receptors and signaling in breast cancer. Curr Cancer Drug Targets 2004, 4, 463470.

[8] Schramm, A., Schulte, J. H., Astrahantseff, K., Apostolov, O., et al., Biological effects of TrkA and TrkB receptor signaling in neuroblastoma. Cancer Lett 2005, 228, 143-153.

[9] Descamps, S., Lebourhis, X., Delehedde, M., Boilly, B., Hondermarck, H., Nerve growth factor is mitogenic for cancerous but not normal human breast epithelial cells. $J$ Biol Chem 1998, 273, 16659-16662.

[10] Descamps, S., Toillon, R. A., Adriaenssens, E., Pawlowski, V., et al., Nerve growth factor stimulates proliferation and survival of human breast cancer cells through two distinct signaling pathways. J Biol Chem 2001, 276, 17864-17870.

[11] Ohta, T., Watanabe, T., Katayama, Y., Kurihara, J., et al., TrkA expression is associated with an elevated level of apoptosis in classic medulloblastomas. Neuropathology 2006, 26, 170-177.

[12] Adriaenssens, E., Vanhecke, E., Saule, P., Mougel, A., et al., Nerve growth factor is a potential therapeutic target in breast cancer. Cancer Res 2008, 68, 346-351.

[13] Lagadec, C., Meignan, S., Adriaenssens, E., Foveau, B., et al., TrkA overexpression enhances growth and metastasis of breast cancer cells. Oncogene 2009.

[14] McGregor, L. M., McCune, B. K., Graff, J. R., McDowell, P. R., et al., Roles of trk family neurotrophin receptors in medullary thyroid carcinoma development and progression. Proc Natl Acad Sci U S A 1999, 96, 4540-4545.

[15] Ricci, A., Greco, S., Mariotta, S., Felici, L., et al., Neurotrophins and neurotrophin receptors in human lung cancer. Am J Respir Cell Mol Biol 2001, 25, 439-446.

[16] Friess, H., Zhu, Z. W., di Mola, F. F., Kulli, C., et al., Nerve growth factor and its highaffinity receptor in chronic pancreatitis. Ann Surg 1999, 230, 615-624.

[17] Zhu, Z., Friess, H., diMola, F. F., Zimmermann, A., et al., Nerve growth factor expression correlates with perineural invasion and pain in human pancreatic cancer. $J$ Clin Oncol 1999, 17, 2419-2428.

[18] Weeraratna, A. T., Arnold, J. T., George, D. J., DeMarzo, A., Isaacs, J. T., Rational basis for Trk inhibition therapy for prostate cancer. Prostate 2000, 45, 140-148.

[19] Miknyoczki, S. J., Wan, W., Chang, H., Dobrzanski, P., et al., The neurotrophin-trk receptor axes are critical for the growth and progression of human prostatic carcinoma and pancreatic ductal adenocarcinoma xenografts in nude mice. Clin Cancer Res 2002, 8, 1924-1931. 
[20] Campos, X., Munoz, Y., Selman, A., Yazigi, R., et al., Nerve growth factor and its high-affinity receptor trkA participate in the control of vascular endothelial growth factor expression in epithelial ovarian cancer. Gynecol Oncol 2007, 104, 168-175.

[21] Davidson, B., Reich, R., Lazarovici, P., Nesland, J. M., et al., Expression and activation of the nerve growth factor receptor TrkA in serous ovarian carcinoma. Clin Cancer Res 2003, 9, 2248-2259.

[22] Chevallet, M., Tastet, C., Luche, S., Rabilloud, T., Preparing protein extracts for quantitative two-dimensional gel comparison. Curr Protoc Protein Sci 2004, Chapter 22, Unit 2224.

[23] Gorg, A., Postel, W., Gunther, S., Weser, J., et al., Approach to stationary twodimensional pattern: influence of focusing time and immobiline/carrier ampholytes concentrations. Electrophoresis 1988, 9, 37-46.

[24] Tastet, C., Lescuyer, P., Diemer, H., Luche, S., et al., A versatile electrophoresis system for the analysis of high- and low-molecular-weight proteins. Electrophoresis 2003, 24, 1787-1794.

[25] Sinha, P., Poland, J., Schnolzer, M., Rabilloud, T., A new silver staining apparatus and procedure for matrix-assisted laser desorption/ionization-time of flight analysis of proteins after two-dimensional electrophoresis. Proteomics 2001, 1, 835-840.

[26] Neuhoff, V., Arold, N., Taube, D., Ehrhardt, W., Improved staining of proteins in polyacrylamide gels including isoelectric focusing gels with clear background at nanogram sensitivity using Coomassie Brilliant Blue G-250 and R-250. Electrophoresis 1988, 9, 255262.

[27] Com, E., Lagadec, C., Page, A., El Yazidi-Belkoura, I., et al., Nerve growth factor receptor TrkA signaling in breast cancer cells involves KU70 to prevent apoptosis. Mol Cell Proteomics 2007.

[28] Collis, S. J., DeWeese, T. L., Jeggo, P. A., Parker, A. R., The life and death of DNAPK. Oncogene 2005, 24, 949-961.

[29] Muller, C., Paupert, J., Monferran, S., Salles, B., The double life of the Ku protein: facing the DNA breaks and the extracellular environment. Cell Cycle 2005, 4, 438-441.

[30] Cohen, H. Y., Lavu, S., Bitterman, K. J., Hekking, B., et al., Acetylation of the C terminus of Ku70 by CBP and PCAF controls Bax-mediated apoptosis. Mol Cell 2004, 13, 627-638.

[31] Morio, T., Kim, H., Ku, Artemis, and ataxia-telangiectasia-mutated: signalling networks in DNA damage. Int J Biochem Cell Biol 2008, 40, 598-603.

[32] Gama, V., Gomez, J. A., Mayo, L. D., Jackson, M. W., et al., Hdm2 is a ubiquitin ligase of Ku70-Akt promotes cell survival by inhibiting Hdm2-dependent Ku70 destabilization. Cell Death Differ 2009, 16, 758-769.

[33] Yaneva, M., Jhiang, S., Expression of the Ku protein during cell proliferation. Biochim Biophys Acta 1991, 1090, 181-187.

[34] Cai, Q. Q., Plet, A., Imbert, J., Lafage-Pochitaloff, M., et al., Chromosomal location and expression of the genes coding for $\mathrm{Ku} \mathrm{p70}$ and p80 in human cell lines and normal tissues. Cytogenet Cell Genet 1994, 65, 221-227.

[35] Klein, A., Miera, O., Bauer, O., Golfier, S., Schriever, F., Chemosensitivity of B cell chronic lymphocytic leukemia and correlated expression of proteins regulating apoptosis, cell cycle and DNA repair. Leukemia 2000, 14, 40-46.

[36] Pucci, S., Mazzarelli, P., Rabitti, C., Giai, M., et al., Tumor specific modulation of KU70/80 DNA binding activity in breast and bladder human tumor biopsies. Oncogene 2001, 20, 739-747. 
[37] Luk, J. M., Su, Y. C., Lam, S. C., Lee, C. K., et al., Proteomic identification of Ku70/Ku80 autoantigen recognized by monoclonal antibody against hepatocellular carcinoma. Proteomics 2005, 5, 1980-1986.

[38] Seimiya, M., Tomonaga, T., Matsushita, K., Sunaga, M., et al., Identification of novel immunohistochemical tumor markers for primary hepatocellular carcinoma; clathrin heavy chain and formiminotransferase cyclodeaminase. Hepatology 2008, 48, 519-530.

[39] Mahaney, B. L., Meek, K., Lees-Miller, S. P., Repair of ionizing radiation-induced DNA double-strand breaks by non-homologous end-joining. Biochem J 2009, 417, 639-650.

[40] Sawada, M., Hayes, P., Matsuyama, S., Cytoprotective membrane-permeable peptides designed from the Bax-binding domain of Ku70. Nat Cell Biol 2003, 5, 352-357.

[41] Lynch, E. M., Moreland, R. B., Ginis, I., Perrine, S. P., Faller, D. V., Hypoxia-activated ligand HAL-1/13 is lupus autoantigen Ku80 and mediates lymphoid cell adhesion in vitro. Am J Physiol Cell Physiol 2001, 280, C897-911.

[42] Tai, Y. T., Podar, K., Kraeft, S. K., Wang, F., et al., Translocation of Ku86/Ku70 to the multiple myeloma cell membrane: functional implications. Exp Hematol 2002, 30, 212-220.

[43] Ginis, I., Faller, D. V., Hypoxia affects tumor cell invasiveness in vitro: the role of hypoxia-activated ligand HAL1/13 (Ku86 autoantigen). Cancer Lett 2000, 154, 163-174.

[44] Monferran, S., Paupert, J., Dauvillier, S., Salles, B., Muller, C., The membrane form of the DNA repair protein $\mathrm{Ku}$ interacts at the cell surface with metalloproteinase 9. Embo $\mathrm{J}$ 2004, 23, 3758-3768.

[45] Paupert, J., Dauvillier, S., Salles, B., Muller, C., Transport of the leaderless protein Ku on the cell surface of activated monocytes regulates their migratory abilities. EMBO Rep 2007, 8, 583-588. 


\section{Legends}

Figure 1. Detection of Ku86 up-regulation in TrkA overexpressing cells. (A), a representative $2 \mathrm{D}$ gel image after silver staining. The arrow indicates spots corresponding to Ku86. (B), zoomed regions of Ku86 spots. (C) MALDI-TOF spectrum of tryptic digest for Ku86 indentification. (D) A tandem mass spectrum of the doubly-charged ion at $\mathrm{m} / \mathrm{z}$ 1031.24. The bold letters indicate the detected $b$ and $y$ ions matching the predicted ion mass in the database. (E) Peptides sequenced by LC-MS-MS (underlined). The detected fragments (bold letters) by MALDI-TOF are also indicated in the sequence of full-length of Ku86.

Figure 2. Analysis of Ku86 expression by Western blot and real time PCR. (A) Western blotting. Proteins $(200 \mu \mathrm{g})$ were separated in 2D gel and Western blots were performed using an anti-Ku86 antibody. Actin was used to confirm the loading and transfer of equal amounts of protein. (B) Relative levels of Ku86. Quantification was performed by densitometry of spots revealed after Western blot. Values were normalized with actin. Results are the mean of 3 independent experiments. (C) Real time PCR detection of Ku86 mRNA. RPLP0 (human acidic ribosomal phosphoprotein P0) was used as a reference gene.

Figure 3. Identification of Ku proteins after TrkA immunoprecipitation. Lysates from TrkA overexpressing cells were subjected to TrkA immunoprecipitation and the eluates were separated on a $10 \%$ SDS-polyacrylamide gel. (A) SDS-polyacrylamide gel after staining with colloidal Coomassie blue. Arrows indicate positions of Ku86 and Ku70 on the gel, Asterisk indicates IgG. (B and C) Tandem mass spectra of the doubly charged ions at $\mathrm{m} / \mathrm{z}$ 1111.74 for Ku86 and at m/z 1171.71 for Ku70 are indicated. The bold letters indicate the detected $b$ and $y$ ions matching the predicted ion mass in the database. (D) Western blot 
of TrkA co-immunoprecipitated Ku proteins. Lysates from TrkA overexpressing cells were immunoprecipitated with an anti-TrkA antibody. Co-immunoprecipitated proteins were subjected to immunoblot (IB) with anti-TrkA, -Ku86 and -Ku70.

Figure 4. Immuno-detection of $\mathrm{Ku}$ proteins on whole cells. (A and $\mathrm{B}$ ) Detection of membrane Ku proteins by flow cytometry. Mixed mock and TrkA-overexpressing cells were incubated with isotype antibody to establish isotype control. Results are representative of 3 separate experiments carried out in duplicate. (C) Immunofluorescent staining of TrkA and Ku proteins. Subcellular distribution of TrkA and Ku proteins was observed under confocal microscopy after immunostaing. Blue, TrkA; Green, Ku-86 or Ku70.

Figure 5. Involvement of Ku proteins in TrkA-stimulated invasion and survival. (A) Western blot analysis of Ku proteins after siRNA transfection. MDA-MB-231 TrkA overexpressing cells were transiently transfected with siKu86 and/or siKu70, siGFP (Green Fluorescence Protein) was used as control. (B and C) Invasion assay. TrkA overexpressing cells were transfected with siKu (B) or pretreated with neutralizing antibodies for 30 min at $37^{\circ} \mathrm{C}(\mathrm{C})$ and then cultured for $16 \mathrm{~h}$ in Transwells before counting of invasing cells. (D) Apoptosis detection. TrkA overexpressing cells were transfected with siKu and then treated with TRAIL ( $5 \mathrm{ng} / \mathrm{ml})$ for $6 \mathrm{~h}$. Apoptosis was assessed after Hoechst staining. *, $\mathrm{p}<0.01$, siKu70 and siKu86 transfected cells versus siGFP transfected cells, or anti-Ku86 and anti-Ku70 treated cells versus Isotype control antibody treated cells. 
Table 1A. Ku86 identification with MALDI-TOF. Spots indicated in Figure 1 were cut out of the gel and digested with trypsin before MALDI-TOF analysis. Mascot search program was used to identify proteins. The table lists all the 25 peptides identified by MALDI-TOF. The underlined peptides are also identified by nanoLC-nanoESI-MS/MS.

\begin{tabular}{|c|c|c|c|c|}
\hline Position & $\begin{array}{l}\text { Corresponding } \\
\text { peptide sequences }\end{array}$ & $\begin{array}{l}\text { Observed } \\
\text { precursor } \\
m / z\end{array}$ & $\begin{array}{c}\text { Theoretical } \\
\text { precursor neutral } \\
\text { mass }\end{array}$ & $\begin{array}{l}\text { Delta mass } \\
\text { (Da) }\end{array}$ \\
\hline $36-44$ & KVITMFVQR (Ox) & 1136.64 & 1136.64 & 0.00 \\
\hline $37-44$ & VITMFVQR & 992.59 & 992.55 & 0.04 \\
\hline $131-141$ & HIEIFTDLSSR & 1316.69 & 1316.67 & 0.02 \\
\hline $172-184$ & EDGSGDRGDGPFR & 1363.61 & 1363.58 & 0.03 \\
\hline 185-195 & LGGHGPSFPLK & 1108.63 & 1108.60 & 0.03 \\
\hline 196-209 & GITEQQKEGLEIVK & 1570.87 & 1570.86 & 0.01 \\
\hline $243-250$ & HSIHWPCR (Carb) & 1091.59 & 1091.51 & 0.08 \\
\hline $251-260$ & LTIGSNLSIR & 1072.66 & 1072.62 & 0.04 \\
\hline $275-282$ & TWTVVDAK & 918.49 & 918.48 & 0.01 \\
\hline 287-307 & EDIQKETVYCLNDDDETEVLK & 2498.20 & 2498.14 & 0.06 \\
\hline 316-325 & $\underline{\text { YGSDIVPFSK }}$ & 1111.57 & 1111.56 & 0.01 \\
\hline $316-332$ & YGSDIVPFSKVDEEQMK (Ox) & 1986.94 & 1986.92 & 0.02 \\
\hline $354-363$ & RFFMGNQVLK (Ox) & 1254.70 & 1254.65 & 0.05 \\
\hline $355-363$ & FFMGNQVLK (Ox) & 1098.57 & 1098.55 & 0.02 \\
\hline 401-413 & ANPQVGVAFPHIK & 1376.79 & 1376.76 & 0.03 \\
\hline $432-439$ & QYMFSSLK (Ox) & 1018.52 & 1018.48 & 0.04 \\
\hline $444-465$ & YAPTEAQLNAVDALIDSMSLAK (Ox) & 2336.09 & 2336.16 & -0.07 \\
\hline $470-481$ & $\underline{\text { TDTLEDLFPTTK }}$ & 1379.73 & 1379.68 & 0.05 \\
\hline $487-497$ & FQRLFQCLLHR (Carb) & 1516.76 & 1516.81 & -0.05 \\
\hline $490-497$ & LFQCLLHR (Carb) & 1085.61 & 1085.58 & 0.03 \\
\hline $533-543$ & IKTLFPLIEAK & 1271.78 & 1271.79 & -0.01 \\
\hline $535-543$ & TLFPLIEAK & 1030.60 & 1030.61 & -0.01 \\
\hline $546-565$ & DQVTAQEIFQDNHEDGPTAK & 2242.04 & 2242.01 & 0.03 \\
\hline $641-648$ & AFREEAIK & 962.54 & 962.52 & 0.02 \\
\hline 709-732 & DKPSGDTAAVFEEGGDVDDLLDMI (Ox) & 2524.04 & 2524.12 & -0.08 \\
\hline
\end{tabular}


Table 1B. Ku86 identification with NanoLC-nanoESI-MS/MS. Spots indicated in Figure 1 were cut out of the gel and digested with trypsin before nanoLC-nanoESI-MS/MS. Mascot search program was used to identify proteins. The table lists the 5 identified peptides.

\begin{tabular}{lccccc}
\hline Position & $\begin{array}{c}\text { Corresponding } \\
\text { peptide sequences }\end{array}$ & $\begin{array}{c}\text { Observed } \\
\text { precursor } \\
\mathbf{m} / \mathbf{z}\end{array}$ & $\begin{array}{c}\text { Theoretical } \\
\text { mass }\end{array}$ & $\begin{array}{c}\text { Delta mass } \\
\mathbf{( D a )}\end{array}$ & Score \\
\hline $316-325$ & YGSDIVPFSK & 1111.96 & 1111.56 & 0.40 & 45 \\
$355-363$ & FFMGNQVLK & 1082.83 & 1082.56 & 0.27 & 42 \\
$470-481$ & TDTLEDLFPTTK & 1380.05 & 1379.68 & 0.37 & 90 \\
$535-543$ & TLFPLIEAK & 1031.25 & 1030.61 & 0.64 & 45 \\
$546-565$ & DQVTAQEIFQDNHEDGPTAK & 2242.49 & 2242.01 & 0.48 & 21 \\
\hline
\end{tabular}


A

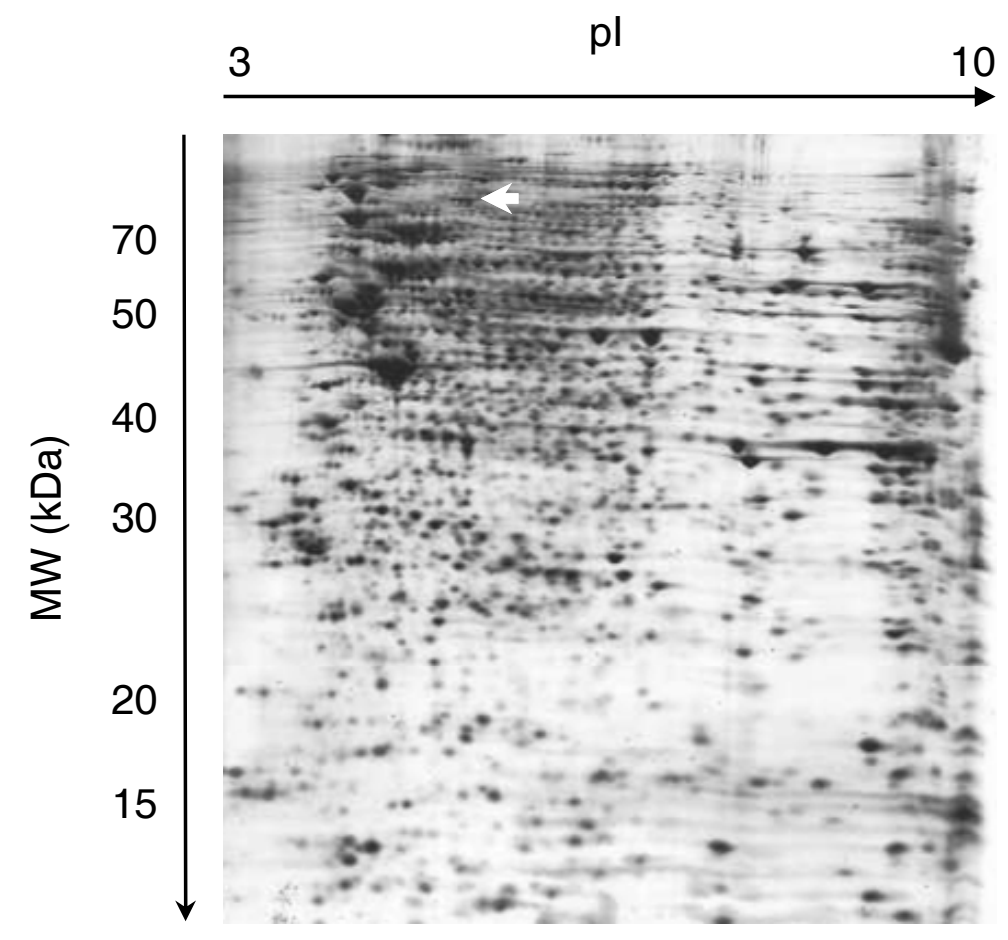

B

Mock

TrkA

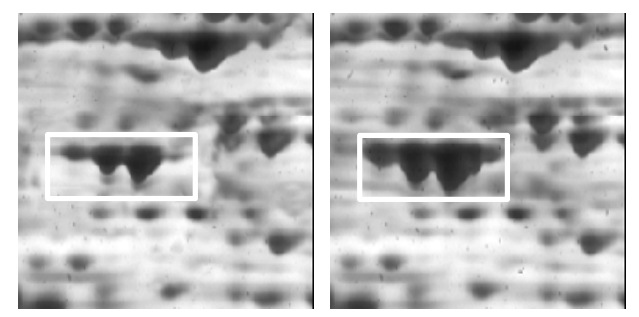

Figure $1 \mathrm{~A}$ and $\mathrm{B}$

Lagadec et al. 
C

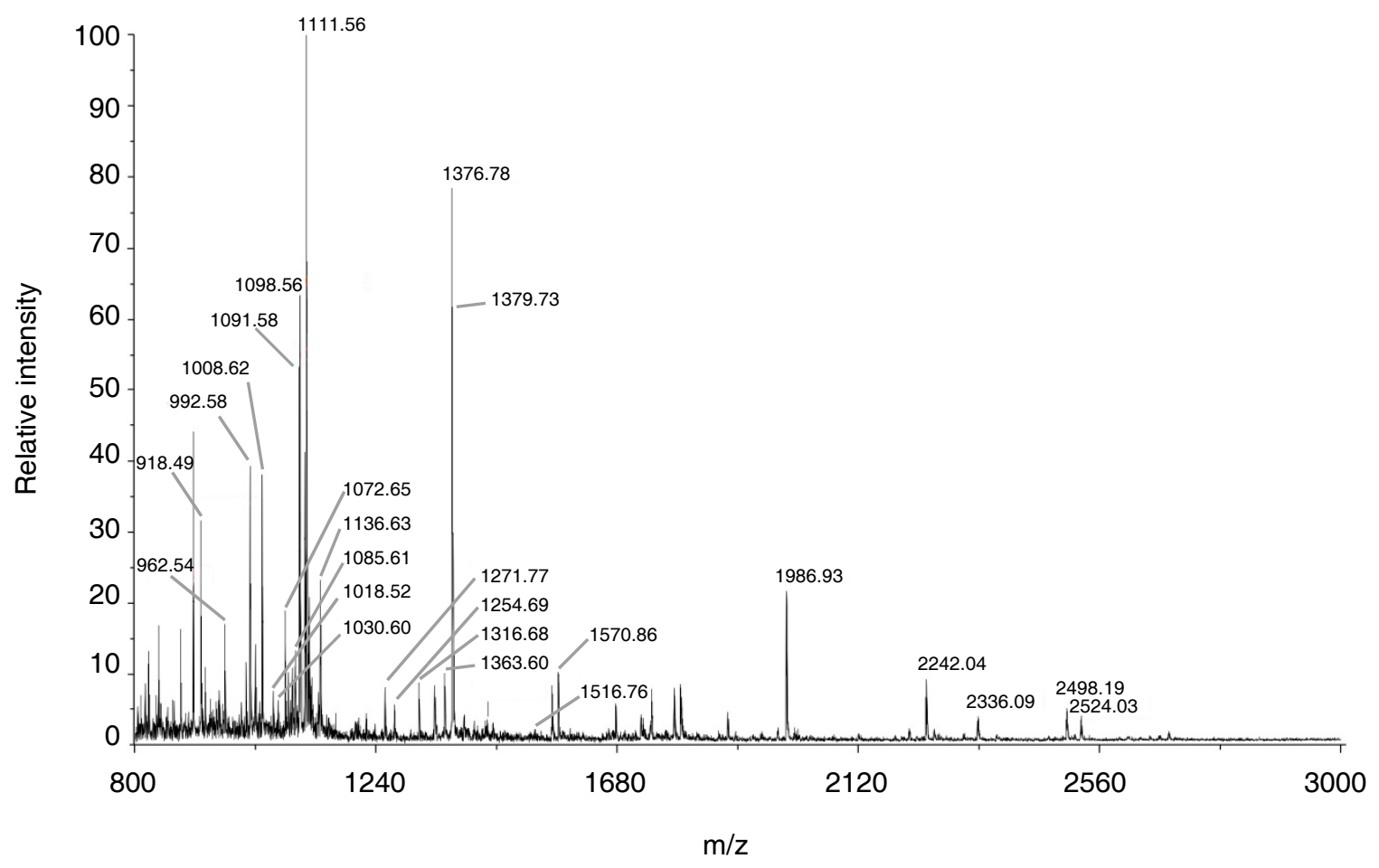

Figure 1C

Lagadec et al. 


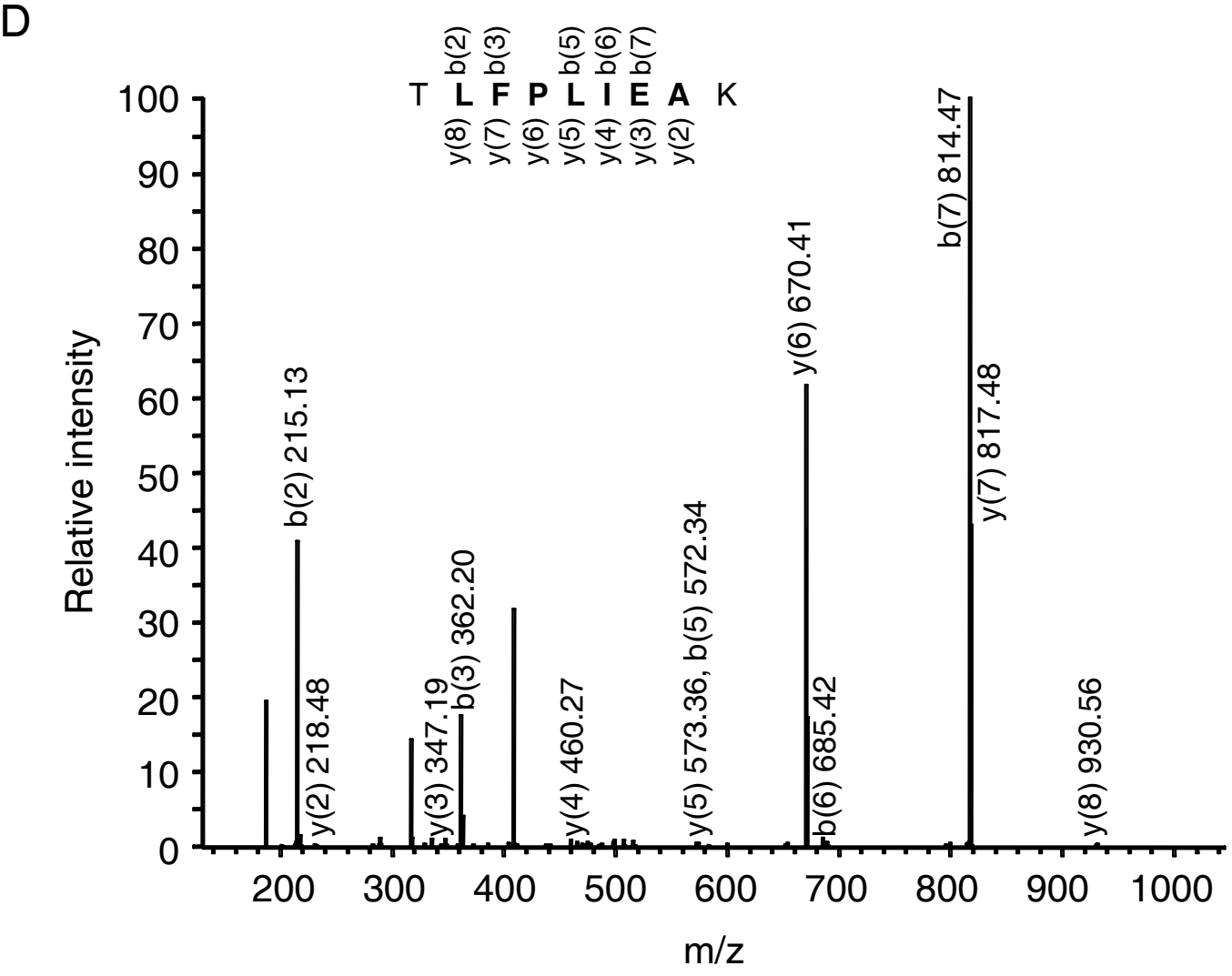

$E$

MVRSGNKAAV VLCMDVGFTM SNSIPGIESP FEQAKKVITM FVQRQVFAEN KDEIALVLFG TDGTDNPLSG GDQYQNITVH RHLMLPDFDL LEDIESKIQP GSQQADFLDA LIVSMDVIQH ETIGKKFEKR HIEIFTDLSS RFSKSQLDII IHSLKKCDIS LQFFLPFSLG KEDGSGDRGD GPFRLGGHGP SFPLKGITEQ QKEGLEIVKM VMISLEGEDG LDEIYSFSES LRKLCVFKKI ERHSIHWPCR LTIGSNLSIR IAAYKSILQE RVKKTWTVVD AKTLKKEDIQ KETVYCLNDD DETEVLKEDI IQGFRYGSDI VPFSKVDEEQ MKYKSEGKCF SVLGFCKSSQ VQRRFFMGNQ VLKVFAARDD EAAAVALSSL IHALDDLDMV AIVRYAYDKR ANPQVGVAFP HIKHNYECLV YVQLPFMEDL RQYMFSSLKN SKKYAPTEAQ LNAVDALIDS MSLAKKDEKT DTLEDLFPTT KIPNPRFQRL FQCLLHRALH PREPLPPIQQ HIWNMLNPPA EVTTKSQIPL SKIKTLFPLI EAKKKDQVTA QEIFQDNHED GPTAKKLKTE QGGAHFSVSS LAEGSVTSVG SVNPAENFRV LVKQKKASFE EASNQLINHI EQFLDTNETP YFMKSIDCIR AFREEAIKFS EEQRFNNFLK ALQEKVEIKQ LNHFWEIVVQ DGITLITKEE ASGSSVTAEE AKKFLAPKDK PSGDTAAVFE EGGDVDDLLD MI 
A

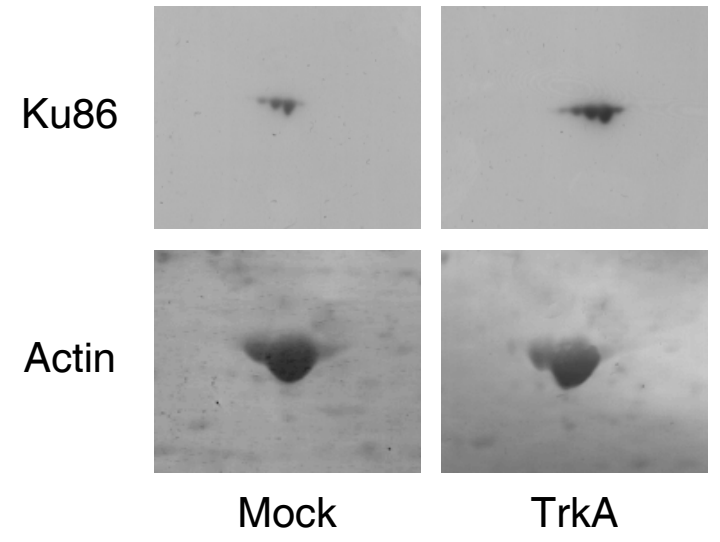

B

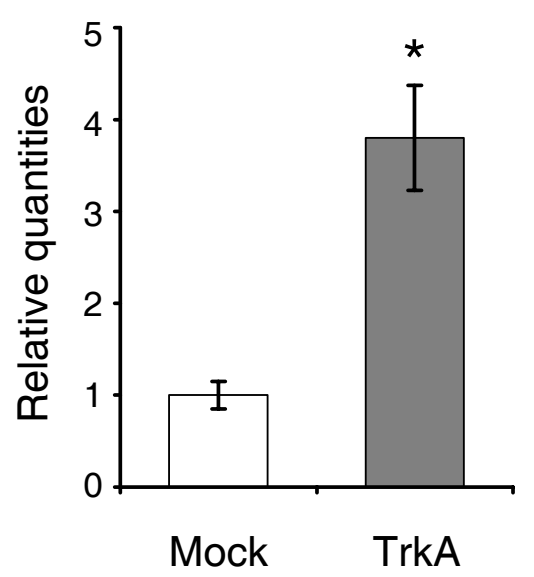

Figure $2 \mathrm{~A}$ and $\mathrm{B}$

Lagadec et al. 
C

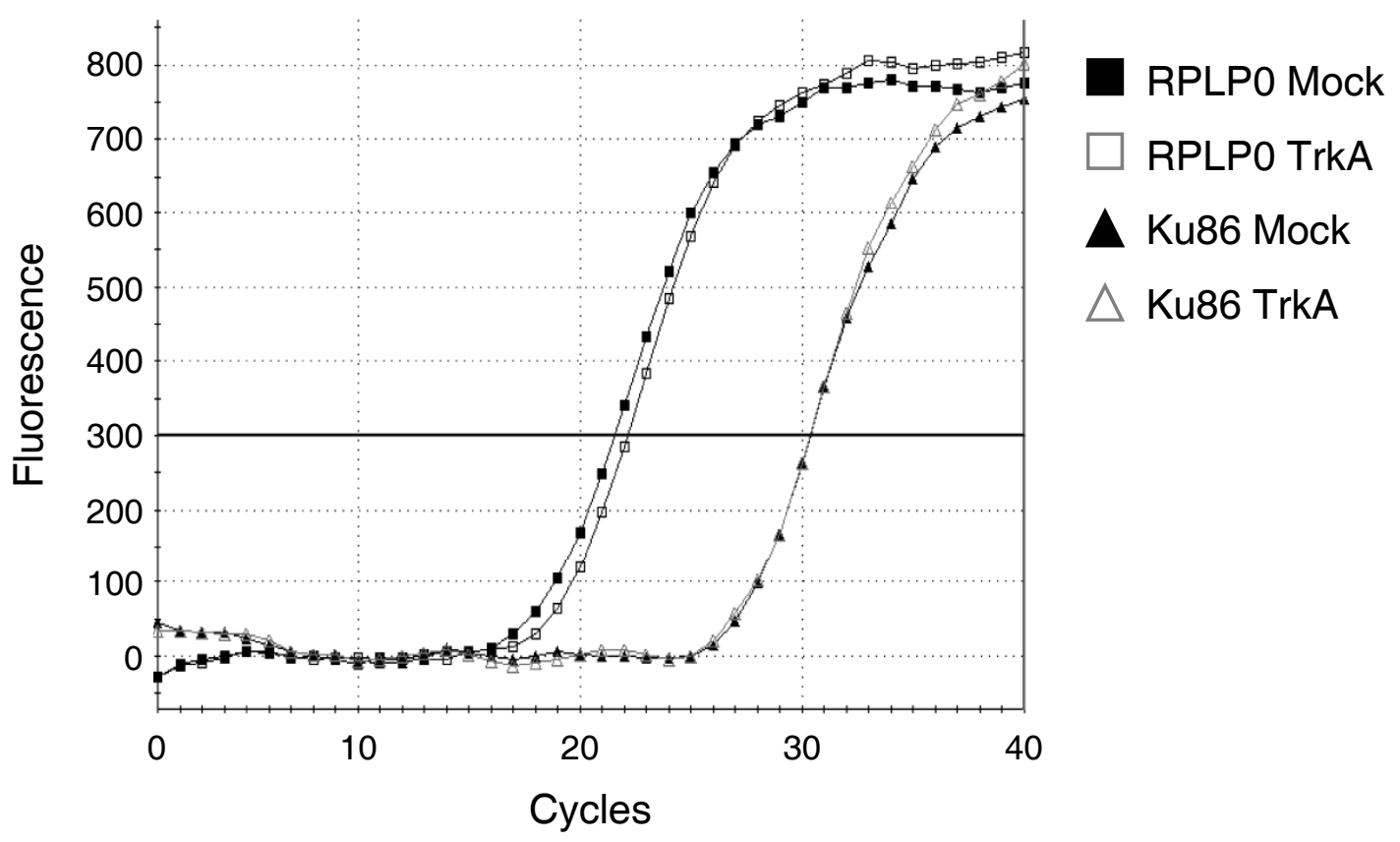

Figure 2C

Lagadec et al. 
A

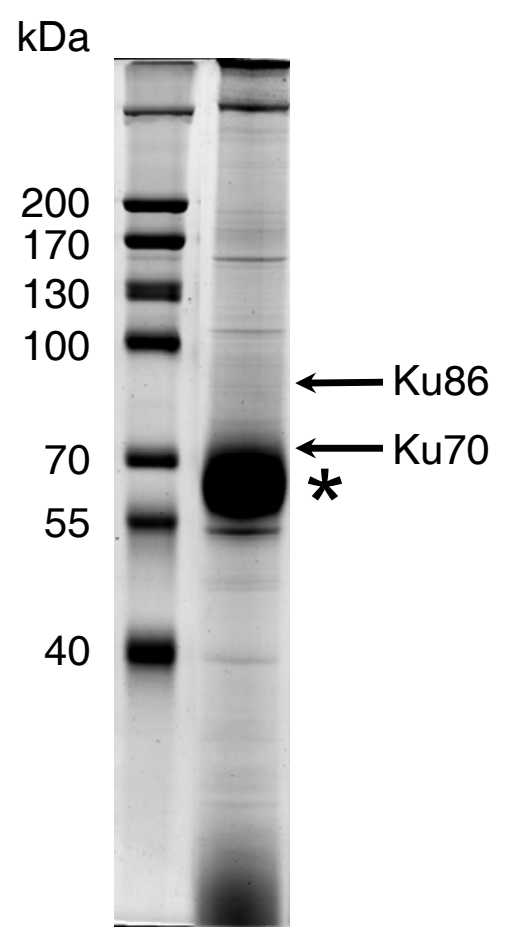

B

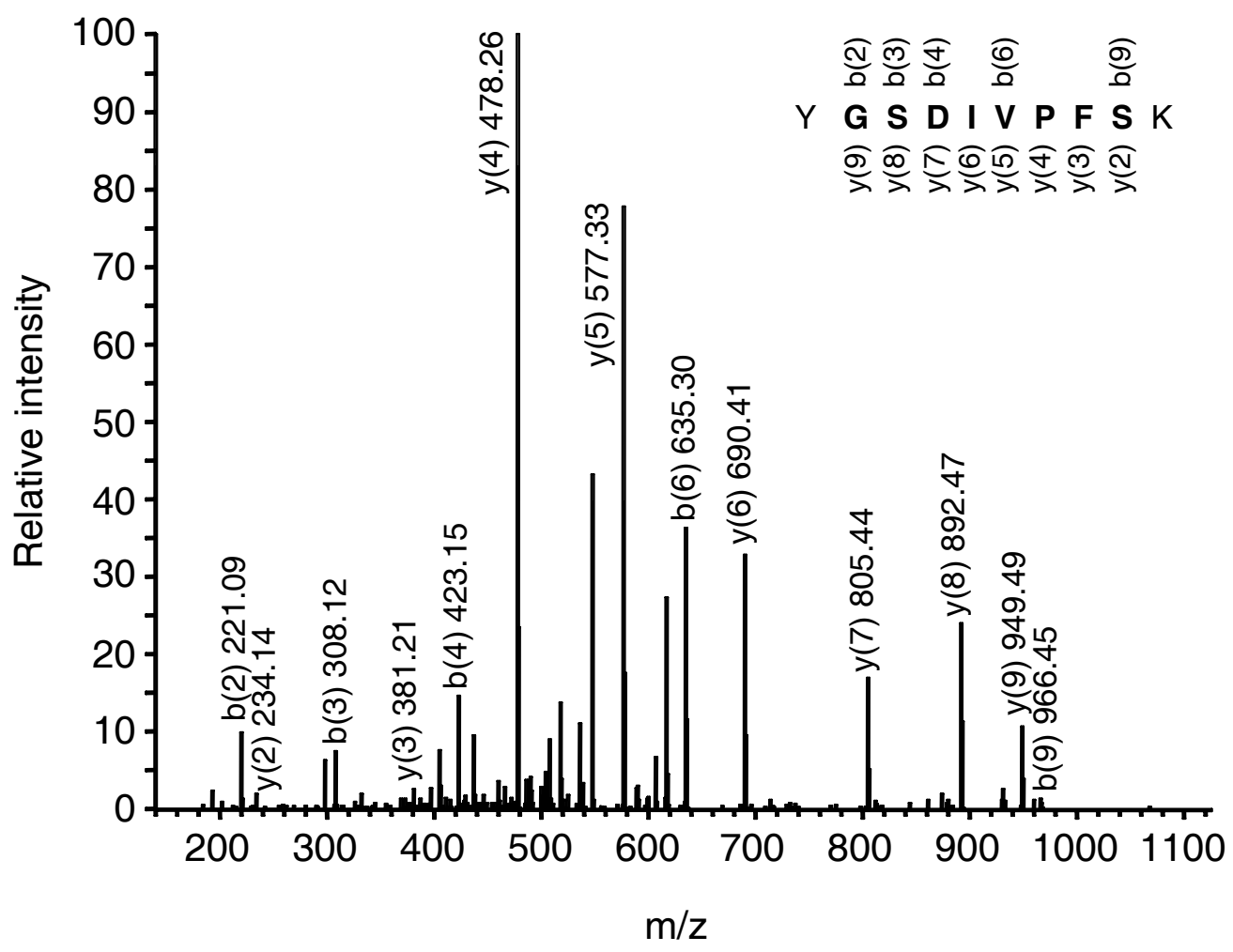

Figure $3 \mathrm{~A}$ and $\mathrm{B}$

Lagadec et al. 
C

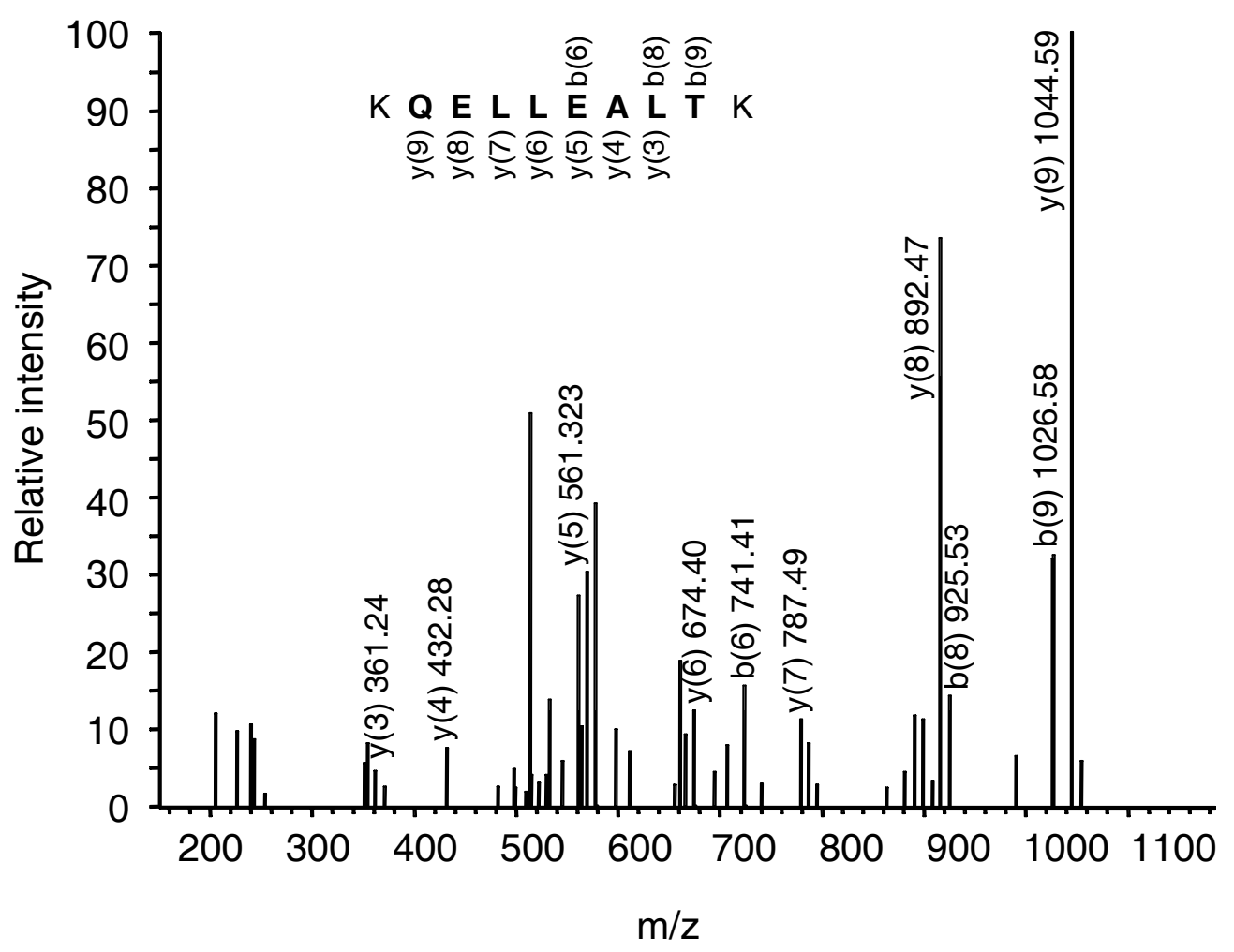

D

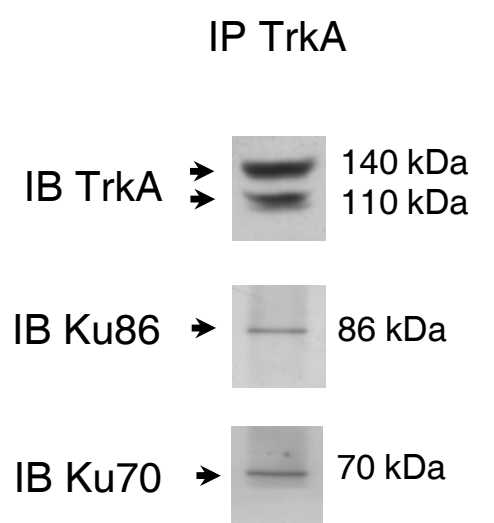

Figure $3 C$ and $D$

Lagadec et al. 
A

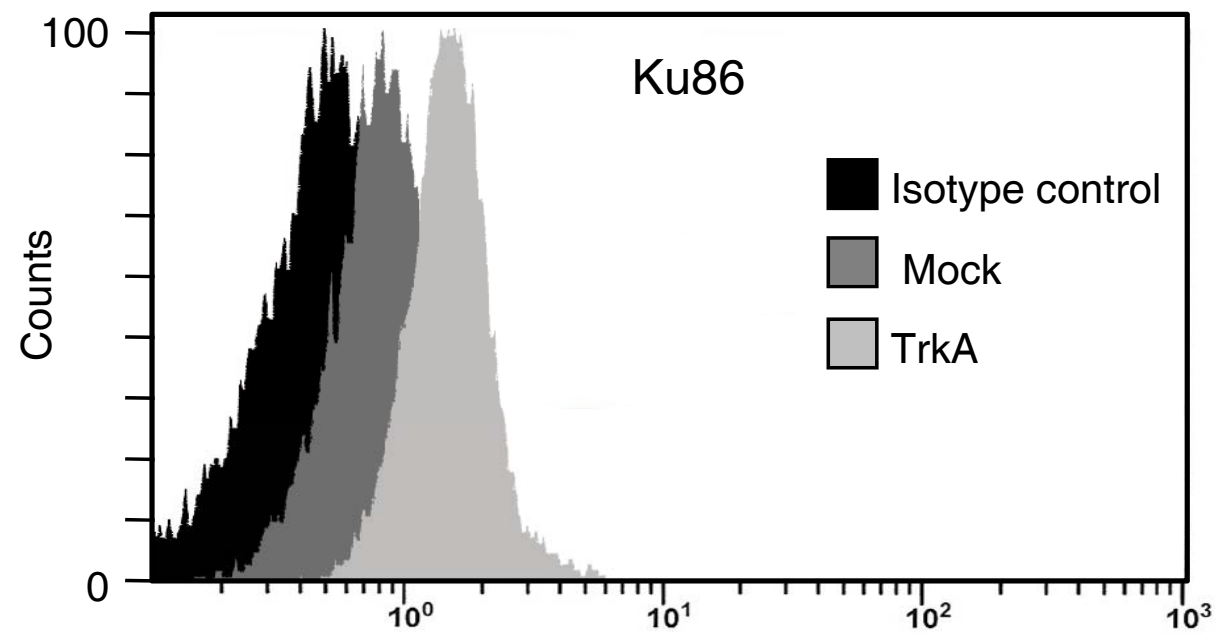

Fluorescence intensity

B

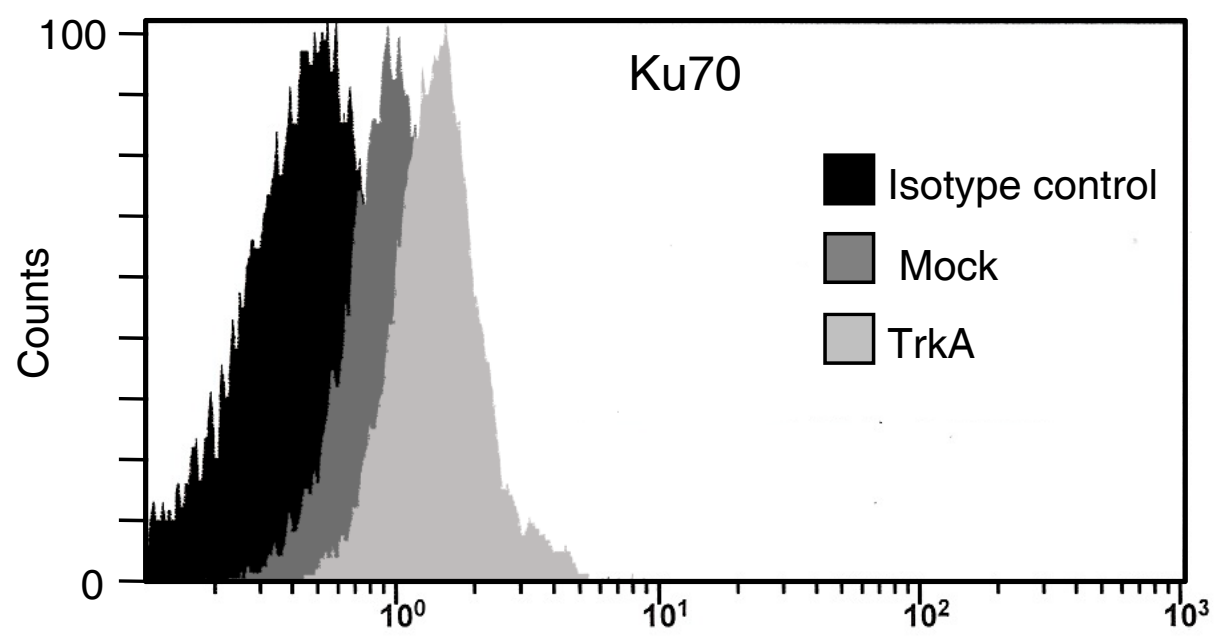

Fluorescence intensity

Figure $4 \mathrm{~A}$ and $\mathrm{B}$

Lagadec et al. 
C
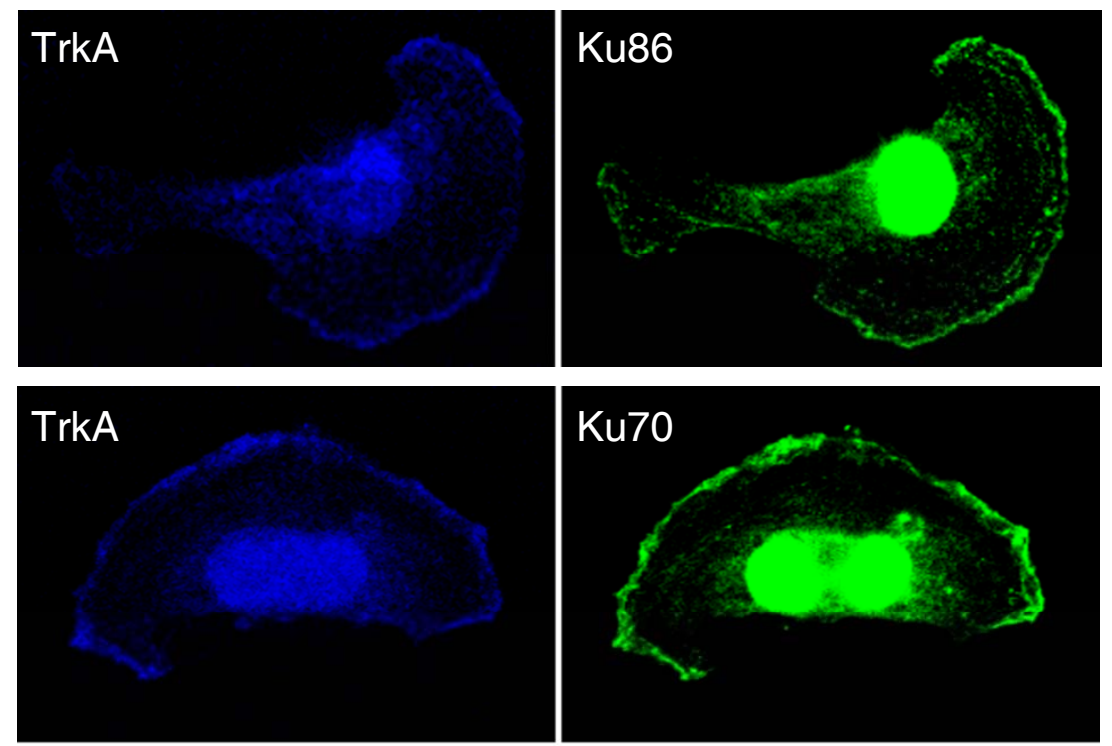

Figure 4C

Lagadec et al. 
A

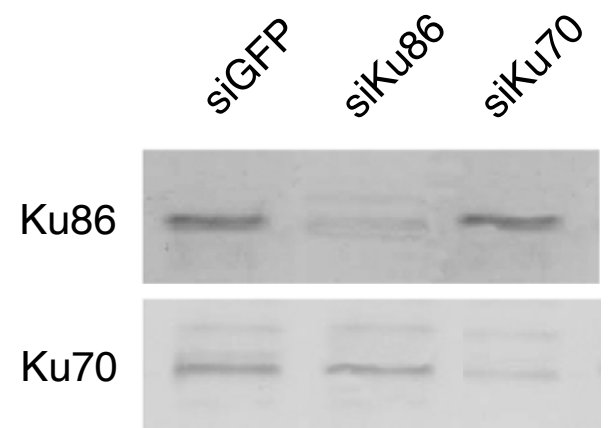

Actin

Figure 5A

Lagadec et al. 
B

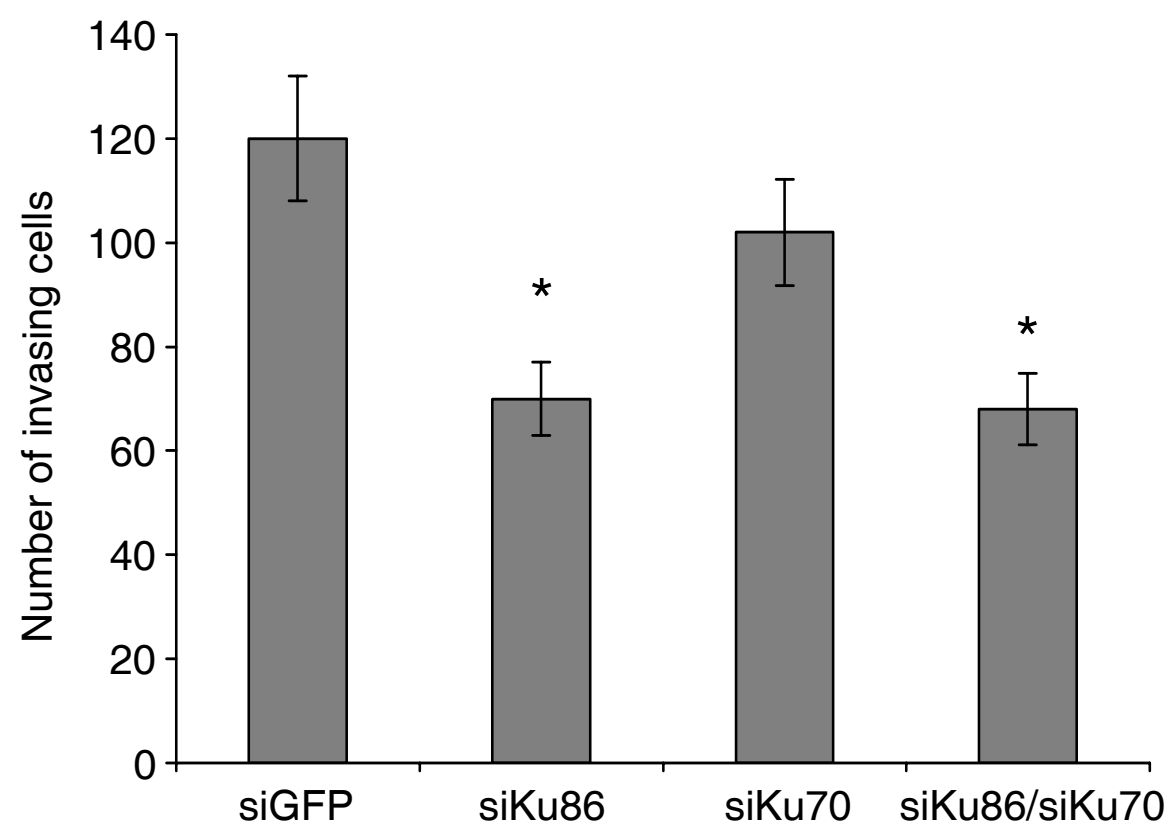

C

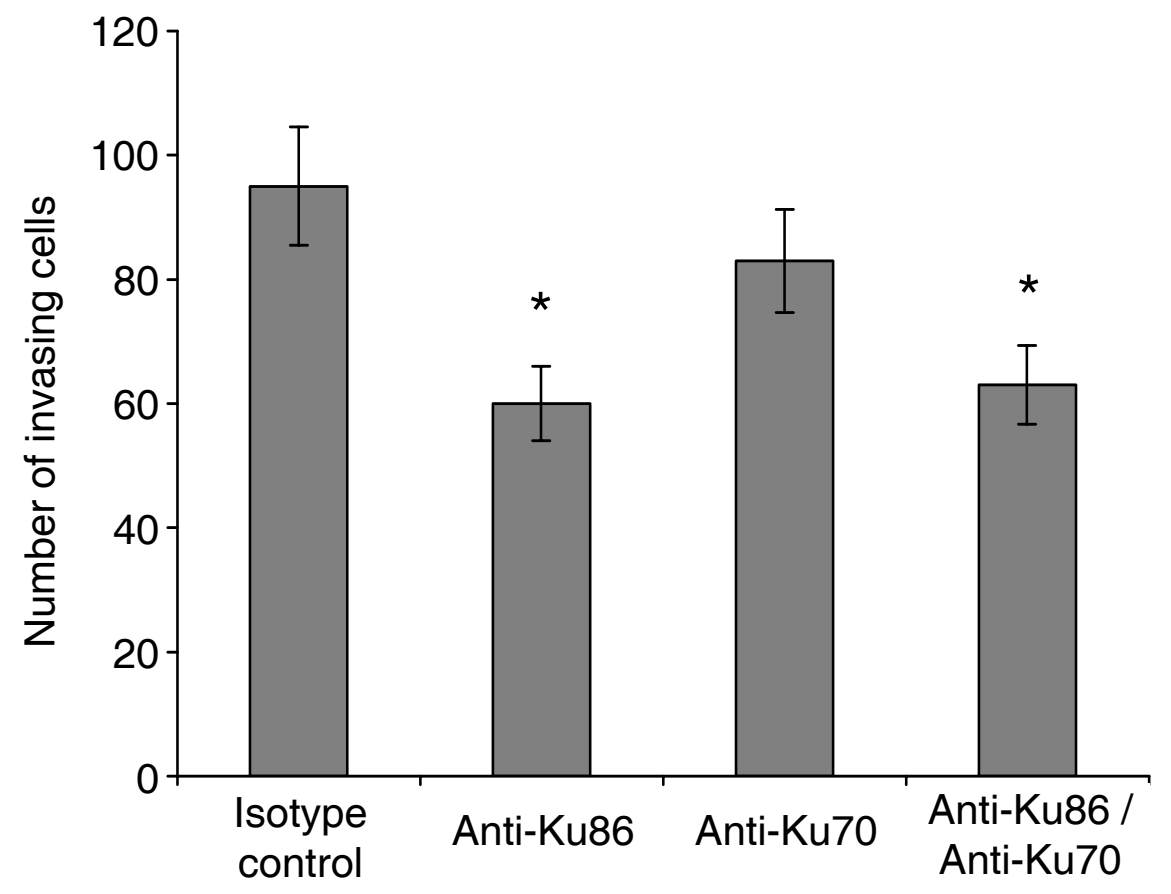

Figure 5B and C

Lagadec et al. 
D

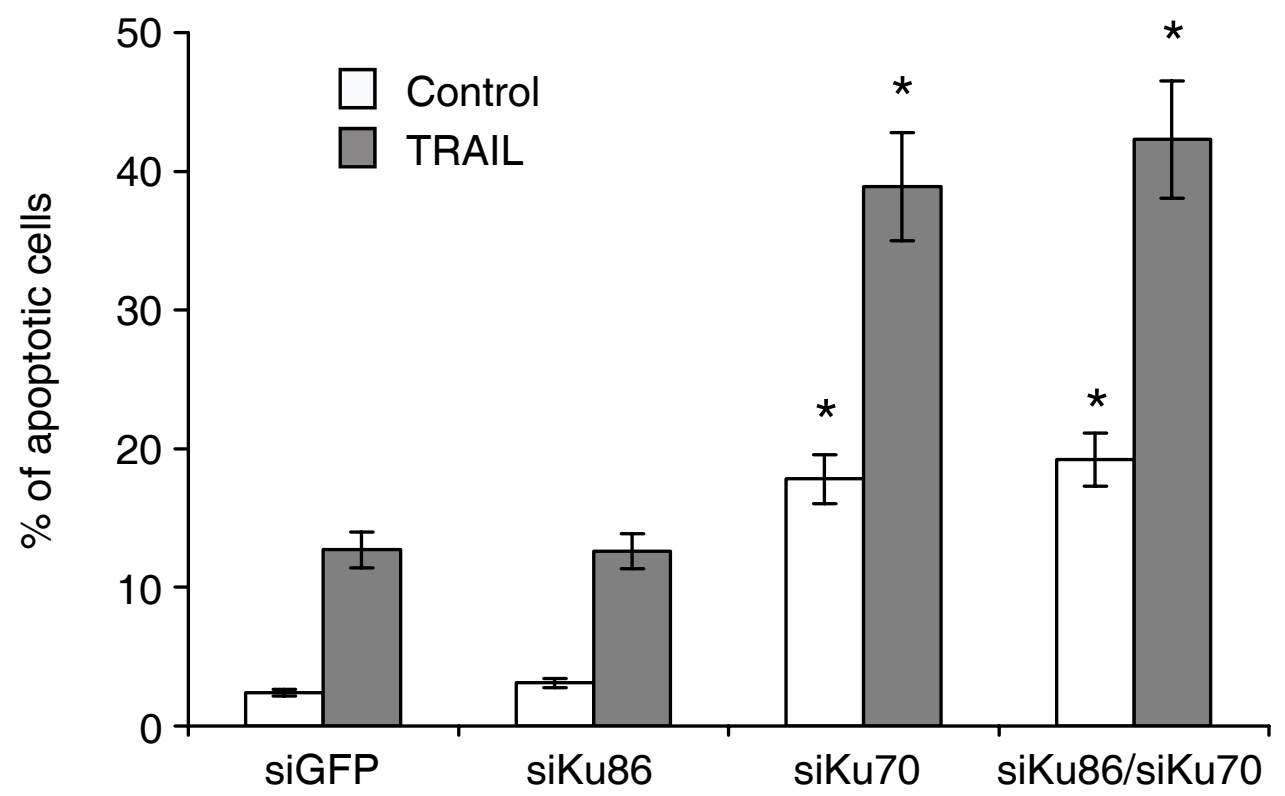

Figure 5D

Lagadec et al. 